\title{
Analysis of Factors Related to Self Management Behavior (SMB) in Hypertensive Patients
}

\author{
Ilkafah \\ Nursing Program, Medical Faculty, Hasanuddin University \\ Makasar, Indonesia \\ ilkafah@unhas.ac.id \\ Titi Iswanti Afelia \\ Nursing Program, Medical Faculty, Hasanuddin University \\ Makasar, Indonesia
}

\author{
Nurul Anugrah Ridwan \\ Nursing Program, Medical Faculty, Hasanuddin University \\ Makasar, Indonesia
}

\begin{abstract}
Hypertension is kind of chronic and risk disease cause the disease complications, to avoid the complications required the ability to self-management behavior such as lifestyle changes including blood pressure control, diet modification and physical activity. This research aimed to determine the factors related to selfmanagement behavior (SMB) in the patients with hypertension in the working area of Batua Makassar. This study was a quantitative study design using analytical survey. Sampling used in this study was purposive sampling techniques, the number of respondents as many as 83 people. The results showed that most respondents education level were high school, the major respondents were women, more than half of respondents aged 56-65 years with an average age of 56 years, and most of respondent had BMI scale $\geq$ 25 with the average value of respondents' BMI were 25.45 , the average respondent had suffered from hypertension for 4.14 years and most do not experience complications. From chi-square analysis test was obtained significant relationship between knowledge, family support, and self-efficacy with SMB in the patients with hypertension in Batua Makassar with p-value (0.001, $0.000,0.000)$. Self-efficacy is the most dominant factor related to SMB of hypertensive patients. There is a relationship between knowledge with the SMB in hypertensive patients, and there is a relationship between family support and self-efficacy with the SMB in hypertensive patients in the working area of Batua Makassar. Where the better level of knowledge, family support and selfefficacy, the better SMB of the patients will be. Therefore, it is expected to self-management Behavior (SMB) can be made as a health promotion program to improve knowledge and the patient's ability to perform SMB.
\end{abstract}

Keywords: Hypertension, self-management behavior, self efficacy, family support

\section{INTRODUCTION}

Hypertension is persistent blood pressure where the systolic pressure is above $140 \mathrm{mmHg}$ and diastolic pressure is above 90 $\mathrm{mmHg}[1]$. Hypertension has been became the world health problem and a major health problem in developed countries (Aster, 2015). Based on data from World Health Organization (WHO) in 2012, there were 839 million cases of hypertension, is estimated will increase to 1.15 billion in 2025 or approximately $29 \%$ of the world population. According to the data of health statistical of the world in hypertension accounted for 9.4 million deaths worldwide[2].
The results of basic medical study (Riskesdas) in 2013 showed the prevalence of hypertension in Indonesia in 2013 as much as $28.1 \%$. Secondary data were obtained from the health department of Makassar, the number of cases of hypertension in South Sulawesi in 2014 were 64.051 cases with 272 deaths due to complications of hypertension and increased in 2015 as many as 73.420 cases of hypertension. High rates of hypertension have an impact on the increased incidence of complications (such as cardiovascular disease, stroke, kidney failure and neurological disorders), there should be an effort to prevent disease complications. Carter et al (2008) cited in Rigsby (2011) asserts that as a result of hypertension experienced by over 70 million people in the United States can increase the risk factor for cardiovascular disease and kidney disease[3]. Intervention in order to lowering blood pressure is handled pharmacologically and non-pharmacologically. Management of hypertension consists of two main approaches i.e. lifestyle modification and pharmacological. Study shows that pharmacological treatment is less effective to control blood pressure without non-pharmacological therapy[4].

Canadian Hypertension Education Program (2011) recommends non-pharmacological management of hypertensive patients such as modifying lifestyle (including dietary modification, BB control, stress management, smoking, blood pressure monitoring, exercise, medication adherence and interaction with health workers). The implementation is called Self-Management Behavior (SMB) in patients with hypertension[5].

SMB in hypertensive patients is a cornerstone for the patients to be able to control and prevent complications occurrence. The effective SMB can help improve the health status and increase the independence of hypertensive patients[6]. SMB in patients with hypertension in the working area of Puskesmas Batua generally has been carried out but the implementation of the SMB are less effective, it proved by the obtained cases of hypertension from Batua in the last two years there was an increase in 2014 as many as 1994 cases, while in 2015 the number of cases of hypertension increased as many as 2,026 cases and mostly occur in the age of $40-64$ years. SMB in patients with hypertension can be influenced several factor. One of the factors that can affect SMB is knowledge, knowledge of patients on hypertension will increase confidence 
and belief to the therapy conducted, another factor is selfefficacy, the patient's belief to therapy conducted[6]. According to Bandura in Komalasari, Wahyuni, \& Karsih (2014) that a person who has a high efficacy tends to work hard and persevere until the task is completed, from the theory it can be concluded that patients who have a high efficacy can improve self-motivation of patient to carry out the therapy.

A study conducted by Mulyati, Yetti, \& Sukmarini (2013) indicated that there were three factors that have a significant relationship with self-management behavior that is selfefficacy, social support and the ability communicate with health care providers. While the level of education, knowledge and duration of pain is not related to self-management behavior in hypertensive patients.

Another study conducted by Crowley et al (2013) about the factors associated with non-compliance with the use of proper medication, diet and exercise on the behavior of self management in patients with hypertension showed that there are two factors related with the poor adherence to behavioral self-management of hypertension i.e. lack of knowledge and belief to therapy factor.

In addition, factor of family support also affects the behavior of patients with hypertension. Family support is divided into instrumental support, emotional, informational and appraisal support. This is according to study conducted by Putry (2016) which stated that there was a relation of family support on the treatment of hypertension patient in Jelbuk, Jember.

Another study conducted by Flynn, et al (2013) in African Americans showed that hypertensive patients have many barriers to self-care management, so that the self-management efforts is less effective in patients with hypertension. In addition, this study also showed that the role of the family is very important in self-management, including providing assistance to the selection of food and help patient with hypertension to adhere the treatment and lifestyle modifications recommended by health professionals.

\section{METHODS}

The method used was quantitative study using analytical survey design with cross-sectional approach which is the study design observe or collect the dependent variable and independent variables while at the same time. The study took place in Batua Makassar. The sampling technique used was purposive sampling, the sample met the criteria to be the respondent and obtained sample as many as 83 respondents.

Data collection in this study was conducted by filling out the questionnaire. The questionnaire in this study consists of five instruments, namely the demographic data of respondents, knowledge about hypertension, family support, self-efficacy, and hypertension self-management behavior questionnaire (HSMBQ) used in measuring the self-management behavior (SMB) of the respondents.

SMB measurements conducted by using the instrument of Hypertension Self-Management Behavior Questionnaire (HSMBQ) adapted from Akher (2010) which has been tested for validity and reliability. Knowledge of hypertension in this study was measured by using questionnaire adapted from Prasetyo (2012) which consist of statements about hypertension, including risk factors and hypertension. Measurement of self-efficacy using questionnaires adapted from Prasetyo (2012) which consists of statements about selfefficacy in hypertensive patients. To measure the level of family support respondents in this study using a questionnaire adapted from Putri (2016) which contains statements about the family support of hypertensive patients which divided into four such as emotional support, instrumental support, informational support and appraisal support.

\section{RESULTS}

This study was conducted in Batua, Makassar. Retrieval of data was conducted over twelve (12) days from October 21st November 2nd, 2016. The data were obtained using 5 questionnaire i.e. demographic data, knowledge about hypertension, family support, self-efficacy, and selfmanagement behaviors given to the respondents who met the inclusion criteria.

Researcher identified the data to determine the respondents who would be involved and then give the research explanation to the respondents. Researcher asked permission to the Respondent to sign the informed consent form that included with instrument sheets. The collected data is processed and analyzed in univariate that includes frequency distribution characteristics of respondents, the level of knowledge, family support, self-efficacy,and self-management behavior of the respondent. The bivariate analysis includes the independent variable relationship with the dependent variable is the relationship between knowledge, family support, self-efficacy on self-management behavior (SMB) in patients with hypertension in Batua Makassar. The results of the study as follows: Characteristics of respondents (Table 1), the level of knowledge of hypertensive patients (Table 2), family support (Table 3), self-efficacy (Table 4), self-management behavior (Table 5), and the relationship between knowledge, family support, self-efficacy on self-management behavior (SMB) in patients with hypertension in Batua Makassar.

TABLE I. DISTRIBUTION CHARACTERISTICS OF RESPONDENTS BY AGE, GENDER, LEVEL OF EDUCATION, BMI, BLOOD PRESSURE, DURATION OF ILLNESS, COMPLICATIONS, AND SMOKING STATUS IN BATUA, MAKASSAR, DURING OCTOBER-NOVEMBER $2016(\mathrm{~N}=83)$

\begin{tabular}{|c|c|c|c|}
\hline & Variable & $\mathbf{N}$ & Presentation \\
\hline \multicolumn{4}{|c|}{ Age } \\
\hline 1. & $40-55$ & 37 & 44,6 \\
\hline 2. & $56-64$ & 46 & 55,4 \\
\hline \multicolumn{4}{|c|}{ Gender } \\
\hline 1. & Male & 31 & 37,2 \\
\hline 2. & Female & 52 & 62,7 \\
\hline \multicolumn{4}{|c|}{ BMI } \\
\hline 1. & $17,0-18,5$ & 3 & 3.6 \\
\hline 2. & $18,5-24,9$ & 26 & 31,3 \\
\hline 3. & $25,0-29,9$ & $\mathbf{5 0}$ & 60,2 \\
\hline 4. & $\geq \mathbf{3 0}$ & 4 & 4,8 \\
\hline \multicolumn{4}{|c|}{ Last Education } \\
\hline & 1.No school & 4 & 4,8 \\
\hline & 2.Elementary & 21 & 25,3 \\
\hline & 3. Junior high school & 24 & 28,9 \\
\hline & 4. Senior high school & 27 & 32,5 \\
\hline & 5.Diploma & 3 & 3,6 \\
\hline
\end{tabular}




\begin{tabular}{|c|c|c|c|c|}
\hline & 6. Bachelor & 4 & 4,8 & \\
\hline \multicolumn{5}{|c|}{ Blood Pressure } \\
\hline \multirow[t]{3}{*}{1.} & Grade 1 of Hypertension: & & & \\
\hline & Systolic 140-159mmHg & 54 & 65,1 & \\
\hline & and diastolic $90-99 \mathrm{mmHg}$ & & & \\
\hline 2. & Grade 2 of Hypertension: & & & \\
\hline$\underline{2}$ & Systolic $\geq 160 \mathrm{mmHg}$ and & 29 & 34,9 & \\
\hline \multicolumn{5}{|c|}{ Diastolic $\geq 100$} \\
\hline \multicolumn{5}{|c|}{ Length of illness } \\
\hline & $\leq 2$ years & 37 & 44,6 & \\
\hline & $>2$ years & 46 & 55,4 & 55 \\
\hline \multicolumn{5}{|c|}{ Complication } \\
\hline 1. & None & 55 & 66,3 & \\
\hline 2. & Diabetic & 13 & 15,7 & \\
\hline 3. & Stroke & 6 & 7,2 & \\
\hline 4. & Kidney disease & 2 & 2,4 & \\
\hline 5. & Others & 7 & 8,4 & \\
\hline \multicolumn{5}{|c|}{ Smoking status } \\
\hline & Smoking & 17 & $\mathbf{2 0 , 5}$ & \\
\hline & Non Smoking & 66 & 79,5 & \\
\hline
\end{tabular}

TABLE II. DISTRIBUTION OF RESPONDENTS BY THE LEVEL OF KNOWLEDGE OF HYPERTENSIVE PATIENTS IN BATUA, MAKASSAR DURING OCTOBER-NOVEMBER $2016(\mathrm{~N}=83)$

\begin{tabular}{ccc}
\hline Knowledge & N & Presentation \\
\hline Good & 60 & 72.3 \\
\hline Poor & 23 & 27.7 \\
\hline Total & 83 & 100.0 \\
\hline
\end{tabular}

TABLE III. DISTRIBUTION OF FAMILY SUPPORT OF HYPERTENSIVE PATIENTS IN WORKING AREA OF PUSKESMAS BATUA MAKASSAR DURING OCTOBER-NOVEMBER $2016(\mathrm{~N}=83)$

\begin{tabular}{ccc}
\hline Family Support & n & Presentations \\
\hline Good & 28 & 33.7 \\
\hline Poor & 55 & 66.3 \\
\hline Total & 83 & 100.0 \\
\hline
\end{tabular}

TABLE IV. ISTRIBUTION OF SELF-EFFICACY OF HYPERTENSIVE PATIENTS IN BATUA MAKASSAR, DURING OCTOBER-NOVEMBER $2016(\mathrm{~N}=83)$

\begin{tabular}{ccc}
\hline Self-efficacy & N & Presentation \\
\hline Both & 38 & 45.8 \\
\hline Poor & 45 & 54.2 \\
\hline Total & 83 & 100 \\
\hline
\end{tabular}

TABLE V. DISTRIBUTION OF SELF MANAGEMENT BEHAVIOR (SMB) IN HYPERTENSIVE PATIENTS IN BATUA, MAKASSAR DURING OCTOBERNOVEMBER $2016(\mathrm{~N}=83)$

\begin{tabular}{ccc}
\hline $\begin{array}{c}\text { Self management behavior } \\
(\text { SMB })\end{array}$ & N & Presentation \\
\hline Good & 37 & 44.6 \\
\hline Poor & 46 & 55.4 \\
\hline Total & 83 & 100.0 \\
\hline
\end{tabular}

TABLE VI. DISTRIBUTION OF THE RELATIONSHIP BETWEEN KNOWLEDGE, FAMILY SUPPORT AND SELF EFFICACY WITH SELF MANAGEMENT BEHAVIOR (SMB) OF HYPERTENSIVE PATIENTS IN BATUA MAKASSAR DURING OKTOBERNOVEMBER $2016(\mathrm{~N}=83)$

\begin{tabular}{|c|c|c|c|c|c|c|c|c|}
\hline \multirow{3}{*}{ Variable } & \multicolumn{4}{|c|}{$\begin{array}{c}\text { Self management behavior } \\
\text { (SMB) }\end{array}$} & \multirow{2}{*}{\multicolumn{2}{|c|}{ Total }} & \multirow{3}{*}{ P Value } & \multirow{3}{*}{$\begin{array}{c}\text { OR } \\
(\mathrm{CI} \\
95 \%)\end{array}$} \\
\hline & \multicolumn{2}{|r|}{ Good } & \multicolumn{2}{|c|}{ Poor } & & & & \\
\hline & n & $\%$ & n & $\%$ & $\mathbf{n}$ & $\%$ & & \\
\hline \multicolumn{9}{|l|}{ Knowledge } \\
\hline Good & 34 & 56,7 & 26 & $\begin{array}{r}43,3 \\
87,0\end{array}$ & $\begin{array}{l}60 \\
23 \\
\end{array}$ & $\begin{array}{l}100,0 \\
100,0\end{array}$ & 0,001 & $\begin{array}{r}6,56 \\
(0,82- \\
52,4)\end{array}$ \\
\hline \multicolumn{9}{|l|}{$\begin{array}{l}\text { Family } \\
\text { support }\end{array}$} \\
\hline $\begin{array}{l}\text { Good } \\
\text { Poor } \\
\end{array}$ & 24 & $\begin{array}{l}85,7 \\
23,6 \\
\end{array}$ & 42 & $\begin{array}{r}14,3 \\
76,4 \\
\end{array}$ & $\begin{array}{r}28 \\
55 \\
\end{array}$ & $\begin{array}{r}100,0 \\
100,0 \\
\end{array}$ & 0,000 & $\begin{array}{r}5,91 \\
(0,65- \\
53,8) \\
\end{array}$ \\
\hline \multicolumn{9}{|l|}{ Self-efficacy } \\
\hline $\begin{array}{l}\text { Good } \\
\text { Poor }\end{array}$ & 35 & $\begin{array}{l}92,1 \\
4,4\end{array}$ & 3 & 95,6 & 38 & $\begin{array}{l}100,0 \\
100,0\end{array}$ & 0,000 & $\begin{array}{c}89,1 \\
(14,2- \\
556)\end{array}$ \\
\hline Total & 37 & 44,6 & 46 & 55,4 & 83 & 100.0 & & \\
\hline
\end{tabular}

* Uji chi-square.

Table 6 shows that of the 60 respondents who have a good knowledge there were 34 respondents $(56.7 \%)$ showed good SMB and 26 respondents (43.3\%) showed poor SMB. Of the 23 respondents who have less knowledge there were three respondents (13.0\%) showed a good SMB and 20 respondents $(87.0 \%)$ showed poor SMB. Based on the analysis results chisquare test obtained value $p=0.001<(\alpha=0.05)$. This means that there is a relationship between knowledge with the SMB in patients with hypertension. The results obtained by analysis of OR value is 6.56. This means that someone who has a high knowledge have the opportunity to perform SMB 6.5 times with good than the respondents who have poor knowledge.

Of the 28 respondents who have good family support, there were 24 respondents (85.7\%) showed good SMB, and 4 respondents (14.3\%) showed poor SMB. Of the 55 respondents who have poor family support, there were 13 respondents who indicate the good SMB and 42 respondents $(76.4 \%)$ showed poor SMB.

Based on the analysis of chi-square test obtained value $\mathrm{p}=$ $0.000<(\alpha=0.05)$. This means that there is a significant relationship between family support with the SMB in patients with hypertension in Batua Makassar. The analysis also obtained OR value as much as 5.91. This means that respondents who have good family support have the 
opportunity to perform SMB 5.9 times with good than the respondents who have poor family support.

Of the 38 respondents who have high self-efficacy there were 35 respondents $(92.1 \%)$ showed good SMB and 3 respondents $(7.9 \%)$ showed poor SMB. Of the 45 respondents who have poor self-efficacy there were two respondents $(4.4 \%)$ showed good SMB and 43 respondents (95.6\%) showed Poor SMB. Based on the results of chi-square analysis obtained value of $p=0,000>(\alpha=0.05)$. This means there is a significant relationship between self-efficacy with SMB in patients with hypertension in Batua Makassar. The analysis also obtained the value of OR is 89.114. This means that respondents who have good self-efficacy have opportunities 89.114 times to perform SMB well than the respondents who have poor self efficacy.

\section{DISCUSSION}

Results of study on the respondents characteristic features of hypertensive patients at Batua Makassar with the number of respondents as many as 83 people, it is obtained almost half of patients with hypertension namely 46 people $(44.6 \%)$ aged 5664 years with an average age of patients was 54.8 years. It is proved that the increasing of person's age, the greater the risk of hypertension. Hypertension is a disease that can occur at any age, but the results were obtained almost half of hypertensive patients aged 56-64 years. It is due to lack of physical activity (exercise) of the respondents and poor healthy lifestyle, thus triggering the occurrence of hypertension.

The Results is in line with the study conducted by Anggra $\&$ Prayityo (2013) at Telaga Murni, West Cikarang showed the results of study that the majority of respondents by age, at most $\geq 40$ years, i.e. 19 people $(55.9 \%)$.

Study on gender obtained more than half of the respondents were female as many as 52 people $(62.7 \%)$. The result showed that the average respondent in this study were female. The results also found an increase in blood pressure in women respondents often due to unhealthy behaviors including the consumption of fatty foods and lack of physical activity, as well as stress factors. The Results of study is in line with the study conducted by Annisa, Wahiduddin, and Ansar (2014) at Pattingaloang Makassar city showed that of the 130 samples contained 84 people $(64.6 \%)$ were women.

Study on BMI obtained the majority patients had BMI scale at 25.0 to 29.9 as many as 50 people $(60.2 \%)$. The results also obtained by the average value of BMI in hypertensive patients were 25.5. This means that average respondents in this study were excessive weight (overweight). Someone with excessive weight (overweight) and obesity tend to be more at risk of developing hypertension because of high levels of cholesterol serum in the body that will affect the risk of increased blood pressure[7].

Obesity increases cardiac work and oxygen requirements and contribute to a passive lifestyle. Excessive body fat (especially abdominal obesity) and the ineffectiveness of physical activity will cause insulin resistance which will lead to the occurrence of hypertension[8]. Research is in the study conducted by Ilkafah (2016) in the Batua, Makassar showed that more than the majority of respondents (57\%) were included in the overweight of BMI.
Based on a study of the respondents' education level obtained more than a small number of respondents $(32.5 \%)$ had a high school education level, (4.8\%) had a Diploma and $(4.8 \%)$ had a bachelor's degree of higher education. This means that almost half of respondents have a high level of education.

According Notoatmodjo (2007) level of education also determines a person's ability to understand the knowledge acquired, i.e. the higher the person's level of education the easier the person receiving the information provided.

In this study, the respondents who had diploma levels, bachelor and most of which have high levels of education middle and high school show good level of knowledge, while those respondents who have no school and half of the respondents who have elementary levels of education showed poor knowledge. This can mean that education and knowledge is directly proportional, which means that the higher the level of person's education, the better knowledge will be.

The results were obtained more than half $(55.4 \%)$ of patients with hypertension at Batua suffered hypertension more than 2 years. Based on the test results mean value obtained the average respondents in this study have experienced hypertension for 4.1 years. Hypertension is a chronic disease that lasts a lifetime and cannot be cured. Progression of the disease will continue to run for life and can cause a variety of acute and chronic complications[1].

The results were obtained most of the respondents who have a good level of knowledge is a respondent who has been suffering from hypertension more than 2 years. This means that the longer a person had hypertension then the knowledge of the disease hypertension will also be getting better because respondents who had been suffering from hypertension more than two years was likely to know more about hypertension from experience and information that obtained earlier from health professionals.

Study on the complications of hypertension disease obtained that most of the respondents in this study do not have any complications of the disease and proved from 83 respondents $(66.3 \%)$ without any complications. The results also showed that less than a small number of respondents in this study had diabetes. The result also obtained an average of respondents who have complications of hypertension is the respondent who has been suffering from hypertension more than 2 years. This proves that the longer a person has hypertension, the higher risk of complications of hypertension will be who are unable to control the blood pressure.

Study on smoking status was obtained less than a small number of respondents in this study that have smoking habitual showed from 83 respondents there were 17 respondents $(20.5 \%)$ who smoke. The results also obtained all the respondents who smoke were male. This happened because women have a negative stigma, when smoke, they are seen as bad women. Smoking is a risk factor for hypertension because of the components toxins in cigarettes such as nicotine into the blood vessel, causing a buildup of plaque in blood vessels will cause constriction of the blood vessels and vasoconstriction of blood vessels that lead to the occurrence of hypertension. Smoking habits in a person can cause the adrenergic system and increase blood pressure and vulnerable to atherosclerosis disease. In addition, nicotine can increase blood clotting and blood vessel[9]. 
The results of chi-square obtained analysis test obtained value of $p=0.001<0.05(\alpha)$. This means it can be concluded that there is a significant relationship between the level of knowledge of the SMB in hypertensive patients, where the better a person's level of knowledge of the better SMB shown and vice versa. It can be seen from 83 respondents majority of respondents already know about the definition, signs and symptoms as well as treatment of hypertension but know less about the risk factors of hypertension as well as know less about the therapy that can be conducted to alleviate the blood pressure but drug therapy. The results are consistent with the SMB shown by the majority of hypertensive patients that SMB respondents are still poor because of the lack of knowledge of the risk factors of hypertension and therapies that can alleviate the patient's blood pressure.

Knowledge is the result of knowing and happened after someone did sensing of a particular object. Knowledge is the extent to which a person understands information. Knowledge or cognitive domain is very important in shaping a person's behavior[10].

Basically behavior based knowledge tends to be better than the behavior that is not based on knowledge[11]. The dominant factor influencing coping with hypertension is the level of knowledge. About the SMB is a basic knowledge of the behavior, the level of one's knowledge will have an impact on behavior or lifestyle. This is according to study conducted by Taukhit (2014) which showed that there is a relationship between the levels of knowledge with behavioral prevention of complications of hypertension. This study concluded that the higher one's education, the better prevention behavior of complications of hypertension.

Based on the chi-square analysis obtained $\mathrm{p}$ Value $=0.000$ $<0.05(\alpha)$ it can be concluded that there is a relationship between family support with SMB of hypertensive patients, where the better the level of support the respondent's family the better respondent would show SMB. Based on the study of family support also affects the SMB of hypertensive patients. This is proved from 28 respondents who have good family support there were $(85.7 \%)$ of respondents who expressed good $\mathrm{SMB}$, and of the 55 respondents who have poor family support there were $(76.4 \%)$ of respondents who experienced poor SMB.

The family is a group of two or more individuals who have a special relationship that can be bound by blood or legal relationship. The role of the family in changing the lifestyle and behavior of people is very important in improving the compliance of individuals to make healthy lifestyle behaviors[9].

The result showed that the average respondent had good emotional support and appraisal support. But the respondents get lack instrumental support and informational support. Support from family is an important element in helping individuals to resolve the problem, good family support will grow the high self-confidence and self-motivation in resolving a problem[12].

Family support is divided into four instrumental support, informational support, emotional support, and appraisal supports[10]. The study in line with the study conducted by the Women (2016), which showed that there is a relationship between family support with the treatment of hypertensive patients in the Jelbuk, Jember regency.

Self-efficacy has significant relationships on SMB in hypertensive patients at Batua Makassar. The results of chisquare analysis test obtained p Value $=0.000<0.05(\alpha)$, it proves that there is a relationship between self-efficacy with $\mathrm{SMB}$ in hypertensive patients. Where the better level of respondents self-efficacy, the better SMB will be. Self-efficacy is a person's belief in the ability to organize and implement treatments to achieve the goals set.

Bandura (1997) cited in Komalasari, Wahyuni, \& Karsih (2014) that the Self-efficacy is belief that grows in a person that is based on the existence of motivation and a strong will, and will be evidenced in the form of attitudes and behavior.

Self-efficacy is a factor that affects the SMB of patients because this factor can determine whether a patient can survive even in the implementation there are difficulties and failures (Friedman \& Schustack, 2008). The study showed the majority of respondents who have a good self-efficacy showed a good SMB. From the results it can be concluded that there is a relationship between self-efficacy with SMB in hypertensive patients. This is in line to research conducted by Mulyati, Yetti \& Sukmasari (2013) indicate that there is a significant relationship between self-efficacy with SMB in hypertensive patients.

Self-efficacy can be used as a control mechanism of chronic diseases and is used as a basis to make lifestyle changes. The results were obtained the majority respondents who have good self-efficacy showed good and quite good $\mathrm{SMB}$, and the patients who have poor self-efficacy showed poor SMB. The patient's Self-efficacy is formed from experience in controlling blood pressure, knowledge, selfefficacy also can arise from what people see and encouragement from others.

The study, is in line with the research conducted by Prasad (2013) indicate that there is a significant relationship between self-efficacy with self-care management in patients with hypertension. This study concludes a person who has high selfefficacy will perform with good self-care management.

\section{CONCLUSION AND RECOMMENDATION}

The conclusion in this study is a significant relationship between knowledge, family support and self efficacy against SMB patients with hypertension in the working area of Puskesmas Batua Makassar. Self efficacy is the most influential factor to SMB hypertensive patients. The results of this study suggest for nurses to Self Management Behavior (SMB) can be used as a health promotion program to improve knowledge and the patient's ability to perform SMB.

\section{REFERENCES}

[1] S. C. Smeltzer and B. G. Bare, Buku Ajar Keperawatan Medikal Bedah Brunner \& Suddarth, 8th ed. Jakarta: Buku Kedokteran EGC.

[2] R. R. Dhungana, A. R. Pandey, B. Bista, S. Joshi, and S. Devkota, "Prevalence and Associated Factors of Hypertension: A CommunityBased Cross-Sectional Study in Municipalities of Kathmandu, Nepal," Int. J. Hypertens., vol. 2016, pp. 1-10, May 2016.

[3] B. D. Rigsby, "Hypertension improvement through healthy lifestyle modifications.," ABNF J., vol. 22, no. 2, pp. 41-3, 2011. 
[4] K. Bell, J. Twiggs, and R. Olin, Bernie, "Hypertension: The Silent Killer: Updated JNC-8 Guideline Recommendations Associate Clinical Professor of Pharmacy Practice, Drug Information and Learning Resource Center," 2015

[5] P. Bolli and N. R. C. Campbell, "Do recommendations for the management of hypertension improve cardiovascular outcome? The canadian experience.," Int. J. Hypertens., vol. 2011, p. 410754, 2011.

[6] L. Mulyati, K. Yetti, and L. Sukmarini, "Analisis faktor yang Mempengaruhi Self Managemen Behavior Pada Pasien Hipertensi,” J. Keperawatan Indones., vol. 1, no. 1, pp. 112-123, 2013.

[7] J. M. Black and J. H. Hawks, Keperawatan medikal bedah : manajemen klinis untuk hasil yang diharapkan.
[8] S. A. Price and L. M. Wilson, Patofisiologi Konsep KlinisProses-Proses Penyakit, 6th ed. Jakarta: EGC, 2005.

[9] Potter and Perry, Buku ajar fundamental keperawatan: konsep, proses, dan praktik. Jakarta: EGC, 2006.

[10] S. Notoatmodjo, Promosi Kesehatan dan Perilaku Kesehatan. Jakarta: Rineka Cipta, 2012

[11] Sunaryo, Psikologi Untuk Keperawatan. Jakarta: EGC, 2004.

[12] S. Tamher and Noorkasiani, Kesehatan Lanjut Usia Dengan Pendekatan Asuhan Keperewatan. Jakarta: Salemba Medica, 2009. 